PINHEIRO, JB; SILVA, GO; OLIVEIRA, VR; AMARO, GB; MORAIS, AA. 2019. Prospection of genetic resistance resources to root-knot nematodes in cucurbit genotypes. Horticultura Brasileira 37: 343-347. DOI - http://dx.doi.org/10.1590/S0102-053620190314

\title{
Prospection of genetic resistance resources to root-knot nematodes in cucurbit genotypes
}

\author{
Jadir B Pinheiro' ${ }^{1 \mathbb{D}}$; Giovani Olegario da Silva ${ }^{2} \mathbb{D}$; Valter R Oliveira ${ }^{1 \mathbb{D}}$; Geovani Bernardo Amaro $\mathbb{A}^{\mathbb{D}}$; Alexandre \\ Augusto de Morais ${ }^{1} \mathbb{D}$
}

${ }^{1}$ Embrapa Hortaliças, Brasília-DF, Brasil; jadir.pinheiro@embrapa.br; valter.oliveira@embrapa.br; geovani.amaro@embrapa.br; alexandre.

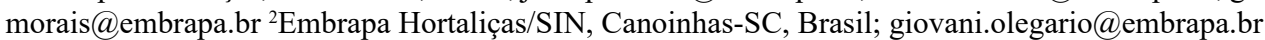

\begin{abstract}
The aim of this research was to prospect genetic resistant sources to root-knot-nematode in Cucurbitaceae accessions. Two assays were conducted, the first to evaluate the resistance to rootknot nematode, $M$. incognita race 1 in accessions of Lagenaria vulgaris; Sicana odorifera; Cucurbita facifolia; Luffa sp.; Citrullus lanatus cv. Citroides; Lagenaria vulgaris; Cucurbita moschata; Cucurbita moschata x Cucurbita maxima; Cucumis melo and Cucumis metuliferus. The second to evaluate the reaction to nematode $M$. incognita race $1, M$. javanica and $M$. enterolobii of the three accessions of Cucumis metuliferus ('Kino') considered resistant to $M$. incognita race 1 in the first experiment. The assays were carried out in a greenhouse at Embrapa Hortaliças in a completely randomized design with six replications. The seedlings in pots were inoculated with 5000 eggs and juveniles of $2^{\text {nd }}$ stage (J2) of each Meloidogyne species alone. Fifty-three and eighty-four days after inoculation, respectively in both experiments, the plants were evaluated for egg mass index (IMO), gall index (IG), number of eggs per gram of root (NEGR) and reproduction factor (RF). The melon Cucumis metuliferus known as 'Kino' was identified as genetic source of resistance to root-knot nematodes and can be explored in breeding program as resistant rootstock.
\end{abstract}

Keywords: Cucurbitaceae, Meloidogyne incognita race 1, M. javanica, M. enterolobii.

\section{RESUMO}

Prospecção de fontes de resistência aos nematoides das galhas em genótipos de cucurbitáceas

O objetivo desse trabalho foi prospectar fontes de resistência aos nematoide-das-galhas em acessos de cucurbitáceas. Foram realizados dois experimentos, o primeiro para avaliar a resistência ao nematoide-das-galhas, $M$. incognita raça 1 em acessos das espécies Lagenaria vulgaris; Sicana odorifera; Cucurbita facifolia; Luffa sp.; Citrullus lanatus cv. Citroides; Lagenaria vulgaris; Cucurbita moschata; Cucurbita moschata x Cucurbita máxima; Cucumis melo e Cucumis metuliferus. O segundo para avaliar a reação aos nematoides $M$. incognita raça $1, M$. javanica e $M$. enterolobii em três acessos de Cucumis metuliferus ('Kino') considerados resistentes a $M$. incognita raça 1 no primeiro experimento. Os experimentos foram conduzidos em casa-de-vegetação na Embrapa Hortaliças, em delineamento inteiramente casualizado com seis repetições. As mudas mantidas em vasos foram inoculadas com 5000 ovos e eventuais juvenis de $2^{\circ}$ estádio (J2) das espécies de Meloidogyne, isoladamente. Cinquenta e três, e oitenta e quatro dias após a inoculação, para os dois experimentos respectivamente, as plantas foram avaliadas quanto ao índice de massas de ovos (IMO), índice de galhas (IG), número de ovos por grama de raiz (NEGR) e fator de reprodução (FR). Verificou-se que a espécie de melão conhecida como 'Kino', é um recurso genético que pode ser explorado para a resistência a $M$. incognita raça $1, M$. javanica e $M$. enterolobii com potencial uso como porta enxerto resistente.

Palavras-chave: Cucurbitaceae, Meloidogyne incognita raça 1, M. javanica, $M$. enterolobii.

\section{Received on November 6, 2018; accepted on August 9, 2019}

\begin{abstract}
$\mathrm{A}$ mong the Cucurbitaceae species cultivated in Brazil are the squashes (Cucurbita moschata), winter squash (Cucurbita maxima), summer squash (Cucurbita pepo), watermelon (Citrullus lanatus), melon (Cucumis melo), cucumber (Cucumis sativus), gherkin (Cucumis anguria) and chayote (Sechium edule) (Ferreira, 2008). The intensive cultivation of this group of vegetables has promoted the development of several diseases,
\end{abstract}

including the occurrence of nematodes, with significant losses in crops due to high infestation. Despite low natural mobility of the nematodes, the constant soil turnover and movement of machinery in the crop areas has favored its spread. Root-knot nematodes of the genus Meloidogyne are very destructive to all cultivated cucurbit species. Meloidogyne incognita, M. javanica and $M$. arenaria are the most important root-knot nematode species in cucurbit crops and are the most common in the world and in Brazil (Pinheiro et al., 2011, 2013).

The Meloidogyne enterolobii specie was discovered in Brazil parasitizing guava plants in São Francisco's region, located in the lower middle Bahia, causing serious damage. It also has been identified as a parasite that affects various vegetable crops in other Brazilian regions, including cucurbits (Damaceno et al., 2016). 
Search for resistance to root nematodes in this family for the use of genes in biotechnological events or as rootstocks becomes important. Franco et al. (2008) and Galatti et al. (2013) identified cucurbit species as sources of resistance to $M$. incognita and with potential for grafting. Ito et al. (2014), also aiming to identify resistance to $M$. incognita and $M$. javanica in accessions of cucurbitaceae, identified resistant and compatible accessions by grafting. Pinheiro et al. (2011) evaluated 13 squash cultivars for $M$. incognita, observed that all squash cultivars were susceptible; the authors highlighted the need to seek for sources of resistance in breeding programs. Similarly Pinheiro et al. (2013) evaluated the resistance of 25 accessions of melon and pumpkins to $M$. incognita race 1 and found that only the access 'Kino' (Cucumis metuliferus) presented resistance. Also for M. incognita, Sigüenza et al. (2005) observed tolerance, but not resistance, in $C$. moschata accessions, whereas $C$. metuliferus rootstock presented little damage and low nematode population. These authors cite several examples of grafting with cucurbit species, for controlling Fusarium in melon, to increase plant vigor in melon and cucumber, and for the vine decline disease (Monosporascus cannonballus) in melon. Resistance to Meloidogyne enterolobii was also been reported in hybrids of $C$. lanatus combined with C. lanatus var. citroides (Damaceno et al., 2016).

The objective of this work was to prospect sources of resistance to gall nematodes in cucurbits accessions.

\section{MATERIAL AND METHODS}

The experiments were conducted in greenhouse and the evaluations were carried out at Embrapa Hortaliças Nematology Laboratory, Brasília, Federal District, Brazil, from October to December 2012 and April to August 2014, using a completely randomized design with six replications.

Twenty-eight melon and squash genotypes were evaluated in the first year for reaction to root-knot nematodes
$M$ incognita race 1 . The following genotypes were evaluated: Bottle Gourd (Lagenaria vulgaris); Sikana (Sicana odorifera); Malabar Gourd Gila (Cucurbita facifolia); Loofah variety (Nova Ponte) (Luffa sp.); Pig Watermelon (Citrullus lanatus cv. citroides); Cabacinha (Lagenaria vulgaris); CNPH 001-Phyt-90Phyt92-1; CNPH 042-Phyt-90; CNPH 043-Phyt-90 (Cucurbita moschata); hybrid pumpkin (Jabras) (Cucurbita moschata x Cucurbita maxima); Melon accessions: CNPH 86-276, CNPH 1962, CNPH 86255, CNPH 87308, CNPH 88442, CNPH 93696, CNPH 93696, CNPH 93731, CNPH 94253, CNPH 92571, CNPH 98307, CNPH 01-963, CNPH 11-1061, CNPH 11-1075, CNPH 11-1076, CNPH 01-930, Neve Melon and BRS Araguaia (Cucumis melo); and Melon Kino. As susceptible standard we used the tomato cultivar 'Rutgers'.

In the second year, 3 accessions of 'Kino' were evaluated: Kino CPACT, Kino Bag and Kino Mendonça, species identified as resistant in the first experiment, for the reaction to nematodes of $M$. incognita race 1 , M. javanica and M. enterolobii. The susceptibility standard was tomato cultivar 'Rutgers' and Cucumis melo BRS Araguaia.

In both assays, females of rootknot nematode were collected from tomato roots in the experimental area of Embrapa Hortaliças; these females were previously identified by isoenzyme standard (Carneiro \& Almeida, 2001) and then subjected to perineal cutting to identify the species according to procedures described by Eisenback \& Hirschmann-Triantaphyllou (1991). After identification, the nematodes were multiplied in Rutgers tomato plants in a greenhouse. Meloidogyne races were identified by the differentiating host test according to Taylor \& Sasser (1978). After identification, inoculation was performed on 'Rutgers' tomatoes, which were kept separately in a greenhouse for production and maintenance of the inoculum. About 45 days after inoculation, eggs and juveniles of second stage (J2) were extracted from the root systems of plants for immediate inoculation of the experiments.
In both experiments, seeds of cucurbit genotypes were sown in 1.0 L plastic pots containing substrate of savanna soil, washed sand, cattle manure and carbonized rice straw, in the ratio $1: 1: 1: 1$. The first trial was sown on October 10, 2012 and the second on April 28, 2014. Six days after direct sowing of three seeds per pot, plantlets were thinned, leaving only one plant per pot. Plants were inoculated with a suspension df 5000 eggs and juveniles of second stage (J2) with the nematodes in cucurbit roots, in $5 \mathrm{~mL}$ water distributed in the pot, around the plant stem.

Evaluations were performed 53 and 84 days after inoculation, respectively for the 2012 and 2014 trials. The following traits were evaluated. Egg mass index (IMO): root systems washed in running water and colored by immersion in Phloxin B solution $0.5 \mathrm{~g} / \mathrm{L}$ water for 15 minutes (Taylor \& Sasser, 1978). The longer time for evaluation after inoculation in the second trial was necessary due to the slower development of the nematodes, observing the roots of the susceptible Rutgers tomato control, probably by sowing season, with milder temperatures. After that, the number of nematode egg masses was counted under a stereomicroscope in the root system of each plant/replication. The IMO in the roots was obtained according to Taylor \& Sasser (1978) using a scale ranging from 0 to 5 , where $0=$ roots without egg masses; $1=1$ to $2 \mathrm{egg}$ masses; $2=3$ to 10 egg masses; $3=11$ to 30 egg masses; $4=31-100$ egg masses and $5=$ over 100 egg masses. The gall index (GI) was also evaluated, which is the number of galls in each root system of each plant/replication. The GI was represented by a scale ranging from 1 to 5, according to Taylor \& Sasser (1978): $0=$ roots without galls; $1=1-2$ galls; $2=$ $3-10$ galls; $3=11-30$ galls; $4=31-100$ galls and $5=$ more than 100 galls. To evaluate the number of eggs per gram of roots (NEGR), at the end of the trial, the roots of all treatments were washed, dried at room temperature for five hours and weighed before being processed according to Hussey \& Barker technique (1973) modified by Bonetti \& Ferraz (1981). The reproductive factor (RF) of the root-knot nematode in the different 
genotypes was obtained by dividing the final and initial population densities $(\mathrm{RF}=\mathrm{Pf} / \mathrm{Pi})$ (Oostenbrink, 1966). We considered as initial population (Pi) the inoculum, quantified and calibrated to contain 5000 eggs and juveniles of second stage (J2) nematodes per pot.

Statistical analyzes, analysis of variance and grouping of means by Scott \& Knott were performed using the
Genes statistical program (Cruz, 2013).

\section{RESULTS AND DISCUSSION}

In the first trial, for all traits, significant differences were noticed $(\mathrm{P}=0.05)$ among genotypes. The coefficients of variation (CV) were higher for NEGR, indicating that this trait was very influenced by the experimental conditions and, therefore, that gives a low reliability to the estimates. Although, the other traits presented reduced $\mathrm{CV}$, ranging from 1.00 to 4.64. The melon genotype 'Kino' presented to be resistant to $M$. incognita race 1 , meanwhile all other genotypes were susceptible (Table 1).

In the second trial, statistical

Table 1. Reaction of cucurbit genotypes to M. incognita race 1 (first trial). Brasilia, Embrapa Hortaliças, 2018.

\begin{tabular}{|c|c|c|c|c|c|}
\hline Genotypes & IMO $^{1}$ & $\mathbf{G I}^{1}$ & NEGR $^{2}$ & $\mathbf{R F}^{3}$ & Reaction $^{4}$ \\
\hline Bottle Gourd & $3.50 \mathrm{c}$ & $5.00 \mathrm{~b}$ & $731.65 \mathrm{a}$ & $9.78 \mathrm{~b}$ & $\mathrm{~S}$ \\
\hline Sikana & $4.00 \mathrm{~d}$ & $5.00 \mathrm{~b}$ & $1471.02 \mathrm{a}$ & $8.02 \mathrm{~b}$ & S \\
\hline Malabar Gourd Gila & $5.00 \mathrm{e}$ & $5.00 \mathrm{~b}$ & $6553.25 \mathrm{~b}$ & $25.37 \mathrm{~d}$ & S \\
\hline Loofah variety Nova Ponte & $4.83 \mathrm{e}$ & $5.00 \mathrm{~b}$ & $3751.36 \mathrm{a}$ & $18.98 \mathrm{c}$ & S \\
\hline Pig Watermelon & $2.66 \mathrm{~b}$ & $5.00 \mathrm{~b}$ & $164.61 \mathrm{a}$ & $2.45 \mathrm{a}$ & $\mathrm{S}$ \\
\hline CNPH-001-Phyt-90, Phy92-1 & $5.00 \mathrm{e}$ & $5.00 \mathrm{~b}$ & $17747.70 \mathrm{~b}$ & $36.82 \mathrm{e}$ & S \\
\hline CNPH-042-Phyt-90 & $4.83 \mathrm{e}$ & $5.00 \mathrm{~b}$ & $13781.54 \mathrm{~b}$ & $38.48 \mathrm{e}$ & $\mathrm{S}$ \\
\hline CNPH-043-Phyt-90 & $5.00 \mathrm{e}$ & $5.00 \mathrm{~b}$ & $6994.19 \mathrm{~b}$ & $17.43 \mathrm{c}$ & S \\
\hline Jabras & $5.00 \mathrm{e}$ & $5.00 \mathrm{~b}$ & $2506.24 \mathrm{a}$ & $24.10 \mathrm{c}$ & $\mathrm{S}$ \\
\hline CNPH 86-276 & $5.00 \mathrm{e}$ & $5.00 \mathrm{~b}$ & $3884.2 \mathrm{a}$ & $26.07 \mathrm{~d}$ & S \\
\hline CNPH 1962 & $4.33 \mathrm{~d}$ & $5.00 \mathrm{~b}$ & 8979.32 b & $15.48 \mathrm{c}$ & $\mathrm{S}$ \\
\hline CNPH 86255 & $4.33 \mathrm{~d}$ & $5.00 \mathrm{~b}$ & $1975.45 \mathrm{a}$ & $19.33 \mathrm{c}$ & S \\
\hline CNPH 87308 & $4.83 \mathrm{e}$ & $5.00 \mathrm{~b}$ & $1784.88 \mathrm{a}$ & $9.58 \mathrm{~b}$ & $\mathrm{~S}$ \\
\hline CNPH 88442 & $3.50 \mathrm{c}$ & $5.00 \mathrm{~b}$ & $1140.68 \mathrm{a}$ & $6.33 \mathrm{~b}$ & S \\
\hline CNPH 93696 & $4.16 \mathrm{~d}$ & $5.00 \mathrm{~b}$ & $3649.71 \mathrm{a}$ & $15.23 \mathrm{c}$ & $\mathrm{S}$ \\
\hline CNPH 93731 & $3.00 \mathrm{~b}$ & $5.00 \mathrm{~b}$ & $4130.42 \mathrm{a}$ & $9.62 \mathrm{~b}$ & $\mathrm{~S}$ \\
\hline CNPH 94253 & $4.66 \mathrm{e}$ & $5.00 \mathrm{~b}$ & $2110.19 \mathrm{a}$ & $16.57 \mathrm{c}$ & $\mathrm{S}$ \\
\hline CNPH 94254 & $5.00 \mathrm{e}$ & $5.00 \mathrm{~b}$ & $3145.40 \mathrm{a}$ & $21.12 \mathrm{c}$ & S \\
\hline CNPH 98071 & $5.00 \mathrm{e}$ & $5.00 \mathrm{~b}$ & $6895.01 \mathrm{~b}$ & $17.75 \mathrm{c}$ & S \\
\hline CNPH 98307 & $5.00 \mathrm{e}$ & $5.00 \mathrm{~b}$ & $4583.54 \mathrm{a}$ & $21.25 \mathrm{c}$ & S \\
\hline CNPH 01-963 & $3.66 \mathrm{c}$ & $5.00 \mathrm{~b}$ & $745.90 \mathrm{a}$ & $7.47 \mathrm{~b}$ & $\mathrm{~S}$ \\
\hline CNPH 11-1061 & $4.80 \mathrm{e}$ & $5.00 \mathrm{~b}$ & $5746.49 \mathrm{~b}$ & $27.98 \mathrm{~d}$ & S \\
\hline CNPH 11-1075 & $4.66 \mathrm{e}$ & $5.00 \mathrm{~b}$ & $3793.32 \mathrm{a}$ & $14.40 \mathrm{c}$ & $\mathrm{S}$ \\
\hline CNPH 11-1076 & $4.50 \mathrm{e}$ & $5.00 \mathrm{~b}$ & $2995.79 \mathrm{a}$ & $17.08 \mathrm{c}$ & S \\
\hline Kino & $1.00 \mathrm{a}$ & $1.83 \mathrm{a}$ & 196.98 a & $0.57 \mathrm{a}$ & $\mathrm{R}$ \\
\hline Neve Melon & $4.16 \mathrm{~d}$ & $5.00 \mathrm{~b}$ & $1764.02 \mathrm{a}$ & $5.77 \mathrm{~b}$ & S \\
\hline CNPH 01-930 & $5.00 \mathrm{e}$ & $5.00 \mathrm{~b}$ & $98938.87 \mathrm{c}$ & $34.52 \mathrm{e}$ & $\mathrm{S}$ \\
\hline BRS Araguaia & $4.50 \mathrm{e}$ & $5.00 \mathrm{~b}$ & $2779.94 \mathrm{a}$ & $18.92 \mathrm{c}$ & $\mathrm{S}$ \\
\hline Rutgers & $5.00 \mathrm{e}$ & $5.00 \mathrm{~b}$ & $2171.39 \mathrm{a}$ & $11.43 \mathrm{~b}$ & $\mathrm{~S}$ \\
\hline Mean & 4.34 & 4.89 & 7417.69 & 17.17 & - \\
\hline CV (\%) & 4.64 & 1.00 & 60.37 & 4.04 & - \\
\hline
\end{tabular}

${ }^{1}$ Egg and gall mass index (IMO and IG, respectively), according to Taylor \& Sasser (1978). $0=$ roots without egg mass and/or gall; $1=$ roots with 1-2 egg masses and/or galls; 2= roots with 3-10 egg masses and/or galls; $3=$ roots with 11-30 egg masses and/or galls; 4= roots with 31-100 egg masses and/or galls; and 5= roots with more than 100 egg masses and/or galls; ${ }^{2} \mathrm{NEGR}=$ number of eggs per gram of roots; ${ }^{3} \mathrm{RF}$ (reproduction factor) $=$ final population/initial population; ${ }^{4}$ Resistance reactions according to Oostenbrink $(1966) . \mathrm{I}=\mathrm{immune}(\mathrm{RF}=0)$; $\mathrm{R}=$ resistant $(\mathrm{RF}<1)$ and $\mathrm{S}=$ susceptible $(\mathrm{RF}>1)$. Means followed by same letters in the column, do not differ from each other by $\mathrm{Scott}-\mathrm{Knott}$ test $(\mathrm{p}<0.05)$. 
Table 2. Reaction of cucurbit genotypes to $M$. incognita race 1, M. javanica and M. enterolobii (second trial). Brasilia, Embrapa Hortaliças, 2018.

\begin{tabular}{|c|c|c|c|c|c|}
\hline \multirow{2}{*}{ Genotypes } & ${ }^{1} \mathrm{IMO}$ & ${ }^{1} \mathrm{IG}$ & ${ }^{2}$ NEGR & ${ }^{3} \mathbf{F R}$ & ${ }^{4}$ Reaction \\
\hline & \multicolumn{5}{|c|}{ M. incognita race 1} \\
\hline Kino CPACT & $5.00 \mathrm{~b}$ & $2.17 \mathrm{a}$ & $142.79 \mathrm{a}$ & $0.08 \mathrm{a}$ & $\mathrm{R}$ \\
\hline Kino BAG & $3.83 \mathrm{a}$ & $2.83 \mathrm{~b}$ & $67.17 \mathrm{a}$ & $0.06 \mathrm{a}$ & $\mathrm{R}$ \\
\hline Kino Mendonça & $4.00 \mathrm{a}$ & $2.67 \mathrm{~b}$ & $60.41 \mathrm{a}$ & $0.03 \mathrm{a}$ & $\mathrm{R}$ \\
\hline BRS Araguaia & $5.00 \mathrm{~b}$ & $4.50 \mathrm{c}$ & $1452.26 \mathrm{~b}$ & $1.83 \mathrm{~b}$ & S \\
\hline Rutgers & $5.00 \mathrm{~b}$ & $5.00 \mathrm{c}$ & $1070.83 \mathrm{~b}$ & $5.12 \mathrm{c}$ & $\mathrm{S}$ \\
\hline Mean & 4.56 & 3.43 & 558.69 & 1.42 & - \\
\hline \multirow[t]{2}{*}{ CV (\%) } & 2.02 & 5.87 & 47.57 & 14.85 & - \\
\hline & \multicolumn{5}{|c|}{ M. javanica } \\
\hline Kino CPACT & $1.67 \mathrm{a}$ & $1.00 \mathrm{a}$ & $48.41 \mathrm{a}$ & $0.02 \mathrm{a}$ & $\mathrm{R}$ \\
\hline Kino BAG & $1.83 \mathrm{a}$ & $1.00 \mathrm{a}$ & $143.47 \mathrm{a}$ & $0.05 \mathrm{a}$ & $\mathrm{R}$ \\
\hline Kino Mendonça & $1.83 \mathrm{a}$ & $1.33 \mathrm{a}$ & $36.57 \mathrm{a}$ & $0.07 \mathrm{a}$ & $\mathrm{R}$ \\
\hline BRS Araguaia & $5.00 \mathrm{~b}$ & $4.83 \mathrm{~b}$ & $2142.89 \mathrm{~b}$ & $4.25 \mathrm{~b}$ & $\mathrm{~S}$ \\
\hline Rutgers & $5.00 \mathrm{~b}$ & $5.00 \mathrm{~b}$ & $1884.05 \mathrm{~b}$ & $6.58 \mathrm{c}$ & $\mathrm{S}$ \\
\hline Mean & 3.06 & 2.63 & 851.07 & 2.19 & - \\
\hline \multirow[t]{2}{*}{ CV (\%) } & 8.38 & 6.57 & 36.57 & 9.25 & - \\
\hline & \multicolumn{5}{|c|}{ M. enterolobii } \\
\hline Kino CPACT & $2.83 \mathrm{a}$ & $2.17 \mathrm{~b}$ & $38.69 \mathrm{a}$ & $0.04 \mathrm{a}$ & $\mathrm{R}$ \\
\hline Kino BAG & $4.33 \mathrm{~b}$ & $2.33 \mathrm{~b}$ & $26.74 \mathrm{a}$ & $0.03 \mathrm{a}$ & $\mathrm{R}$ \\
\hline Kino Mendonça & $2.33 \mathrm{a}$ & $1.67 \mathrm{a}$ & $11.76 \mathrm{a}$ & $0.02 \mathrm{a}$ & $\mathrm{R}$ \\
\hline BRS Araguaia & $5.00 \mathrm{~b}$ & $4.83 \mathrm{c}$ & $2857.89 \mathrm{c}$ & $1.28 \mathrm{~b}$ & S \\
\hline Rutgers & $5.00 \mathrm{~b}$ & $4.33 \mathrm{c}$ & $554.24 \mathrm{~b}$ & $1.87 \mathrm{c}$ & $\mathrm{S}$ \\
\hline Mean & 3.90 & 3.06 & 697.86 & 0.64 & - \\
\hline CV (\%) & 7.70 & 7.38 & 90.76 & 13.37 & - \\
\hline
\end{tabular}

${ }^{1}$ Egg and gall mass index (IMO and IG, respectively), according to Taylor \& Sasser (1978). 0= roots without egg mass and/or gall; $1=$ roots with 1-2 egg masses and/or galls; $2=$ roots with 3-10 egg masses and/or galls; $3=$ roots with 11-30 egg masses and/or galls; 4= roots with 31-100 egg masses and/or galls; and 5= roots with more than 100 egg masses and/or galls; ${ }^{2} \mathrm{NEGR}=$ number of eggs per gram of roots; ${ }^{3} \mathrm{RF}$ (reproduction factor) $=$ final population/initial population; ${ }^{4}$ Resistance reactions according to Oostenbrink $(1966)$. $\mathrm{I}=\mathrm{immune}(\mathrm{FR}=0)$; $\mathrm{R}=$ resistant $(F R<1)$ and $S=$ susceptible $(F R>1)$. Means followed by same letters in the column do not differ from each other by Scott-Knott test $(\mathrm{p}<0.05)$.

significance was observed $(\mathrm{P}=0.05)$ in all traits on the evaluated genotypes. In the same way as in the first assay, the coefficients of variation $(\mathrm{CV})$ were higher for NEGR in the evaluation of all nematode species. We also observed the resistance of 'Kino' melon for the three evaluated accessions and for three species of root-knot nematodes (Table 2). This fact confirms that 'Kino' melon is a potential genetic resource of resistance against root-knot nematode species.

Pinheiro et al. (2011) evaluated the behavior of 13 commercial squash cultivars for resistance to Meloidogyne incognita race 1 and all were susceptible to this species, emphasizing the need of resistance sources against rootknot nematode in squash breeding programs. Similarly, Pinheiro et al. (2013) evaluated the resistance of 25 melon and pumpkin accessions to Meloidogyne incognita race 1 and observed that only the accession 'Kino' presented resistance.

Sigüenza et al. (2005) evaluated the use of Cucurbita moschata and Cucumis metuliferus as rootstocks for the management of Meloidogyne incognita, and verified that $C$. moschata rootstocks inoculated with the nematode were tolerant but not resistant. The inoculated C. metuliferus rootstock presented little damage and a low nematode population. The authors pointed that high prices and restrictions of nematicides in grafting could become an economically viable method for the control of root-knot nematodes. The results obtained for $C$. metuliferus by Sigüenza et al. corroborate the results obtained in our study, where a low reproduction factor was observed for both experiments and nematode species (Tables 1 and 2).

Franco et al. (2008) studied the reaction to $M$. incognita of 16 Cucurbitaceae genotypes with potential for grafting with muskmelon. The genotypes were evaluated based on 
the reproduction factor being observed that the loofah, pumpkin 'Goianinha', pumpkin 'Mini Paulista', melon 'Redondo Amarelo' and watermelon Charleston Gray were resistant genotypes.

Ito et al. (2014) evaluated 33 cucurbit accessions to the nematodes $M$. incognita and $M$. javanica and verified that melon genotypes CNPH 01-930, CNPH 01-962, CNPH 01-963, 'Redondo Gaucho' and Wax Gourd (Benincasa hispida) were considered resistant to $M$. incognita with reproduction factors less than $1(\mathrm{FR}<1)$; 'Redondo Amarelo' melon, 'Charleston Gray' watermelon, 'Coréia' progeny (Citrullus lanatus), and Trichosanthes cucumerins, were resistant to $M$. javanica. Benincasa hispida was resistant to both species. Grafting compatibilities between resistant rootstocks and muskmelons were greater than $98 \%$. However, the classification of melon accessions CNPH 01-930, CNPH 01-962, CNPH 01-963 to be resistant to $M$. incognita differ from the results of this study, which were considered susceptible.

In a similar study, Galatti et al. (2013) evaluated 16 cucurbit accessions for $M$. incognita and performed a graft compatibility study with a muskmelon cultivar and found that the genotypes loofah (Luffa cylindrica), pumpkin 'Goianinha' and pumpkin 'Mini Paulista' (Cucurbita moschata), melon 'Redondo Amarelo' (Cucumis melo), Charleston Gray watermelon (Citrullus lanatus), were resistant to $M$. incognita . The best compatibility occurred with the "Canary Melon" rootstocks, which had $100 \%$ establishment, followed by the pumpkin 'Mini Paulista' with 94\%. Loofah, watermelon 'Charleston Gray' and pumpkin 'Goianinha' had low establishment percentages: $66 \%, 62 \%$ and $50 \%$ respectively.

Thus, we concluded that the species 'Kino' is a genetic resource that can be exploited for resistance to the root-knot nematodes $M$. incognita race $1, M$. javanica and M. enterolobii.

\section{REFERENCES}

BONETTI, JIS; FERRAZ, S. 1981. Modificações do método de Hussey \& Barker para extração de ovos de Meloidogyne exigua em raízes de cafeeiro. Fitopatologia Brasileira 6: 553p.

CARNEIRO, RMDG; ALMEIDA, MRA. 2001. Técnica de eletroforese usada no estudo de enzimas dos nematoides de galhas para identificação de espécies. Nematologia Brasileira 25: 35-44.

CRUZ CD. 2013. Genes: a software package for analysis in experimental statistics and quantitative genetics. Acta Scientiarum Agronomy 35: 271-276.

DAMACENO, LS; QUEIROZ, MA; DIAS, RCS; CASTRO, JMC; TEIXEIRA, FA. 2016. Avaliação de parentais e F1s em melancia quanto à reação ao Meloidogyne enterolobii. Revista Caatinga 29: 296-304.

E I S ENB A C K, JD; HIR SCHMANN TRIANTAPHYLLOU, H. 1991. Root-knot nematodes: Meloidogyne species and races. In: WR, NICKLE (ed). Manual of Agricultural Nematology, New York. p.191-274.

FRANCO, AJ; CHARLO, HCO; GALATTI, FS;
BRAZ, LT. 2008. Avaliação de genótipos de cucurbitáceas quanto à resistência à Meloidogyne incognita. Horticultura Brasileira 26: S3650-3654.

FERREIRA, MAJF. 2008. Abóboras e morangas. In: BARBIERI, RL; STUMPF, ERT. Origem e evolução de plantas cultivadas. Brasília: Embrapa Informação Tecnológica, p.59-88.

GALATTI, FS; FRANCO, AJ; ITO, LA; CHARLO, HO; GAION, LA; BRAZ, LT. 2013. Rootstocks resistant to Meloidogyne incognita and compatibility of grafting in net melon. Revista Ceres 60: 432-436.

HUSSEY, RS; BARKER, KR. 1973. A comparison of methods of collecting inocula of Meloidogyne spp. Including a new technique. Plant Disease Reporter 57: 1025-1028.

ITO, LA; GAION, LA; GALATTI, FS; BRAZ, LT; SANTOS, JM. 2014. Resistência de porta-enxertos de cucurbitáceas a nematóides e compatibilidade da enxertia em melão. Horticultura Brasileira 32: 297-302.

OOSTENBRINK, M. 1966. Major characteristics of the relation between nematodes and plants. Mededelingen Landbouw 4: 1-46.

PINHEIRO, JB; AMARO, GB; CARVALHO, ADF; SOUSA, NYC. 2011. Reação de cultivares de abóboras a Meloidogyne incognita raça 1. In: Anais do $6^{\circ}$ Congresso Brasileiro de Melhoramento de Plantas. Resumo expandido. 4p. CD ROM.

PINHEIRO, JB; RODRIGUES, CS; PEREIRA, RB; AMARO, GB; OLIVEIRA, VR; CARVALHO, ADF. 2013. Reação de Cucurbitáceas a Meloidogyne incognita raça 1. In: Anais do $7^{\circ}$ Congresso Brasileiro de Melhoramento de Plantas. Uberlândia-MG. p. 952-955.

SIGÜENZA, C; SCHOCHOW, M; TURINI, T; PLOEG, A. 2005. Use of Cucumis metuliferus as a rootstock for melon to manage Meloidogyne incognita. Journal of Nematology 37: 276-280.

TAYLOR, A; SASSER, JN. 1978. Biology, identification and control of root-knot nematodes (Meloidogyne species). USA: North Caroline State University Graphics. $111 \mathrm{p}$. 